\title{
Optimization of the temperature for the production of synthetic wollastonite based on rice husk
}

\author{
(C) Elena M. Gotlib, ${ }^{1 *}$ Ilia D. Tverdov, ${ }^{2}$ \\ Thi Nha Phuong Ha, ${ }^{1,4}$ and Ekaterina S. Yamaleeva ${ }^{3+}$ \\ ${ }^{1}$ Department of Synthetic Rubber Technology. Kazan National Research Technological University. \\ Karl Marx St., 68. Kazan, 420015. Republic of Tatarstan. Russia. \\ Phone: +7 (843) 231-44-39.E-mail: egotlib@yandex.ru \\ ${ }^{2}$ Complex laboratory "NanoAnalytics". Kazan National Research Technological University. \\ St. Petersburg. 50, building 26. Kazan, 420107. Republic of Tatarstan. Russia. \\ Phone: +7 (843) 227-40-93. E-mail: idtverdov@gmail.ru \\ ${ }^{3}$ Department of Medical Engineering. Kazan National Research Technological University. \\ Karl Marx St., 68. Kazan, 420015. Republic of Tatarstan. Russia. \\ Phone: +7 (843) 231-43-36.E-mail: curls888@yandex.ru \\ ${ }^{4}$ Department of Chemistry. Viet Tri University of Industry. Tien Son St., 9, Viet Tri city, Phu Tho, Vietnam. \\ Phone:+7 (906) 322-42-33.E-mail:phuonghtn@vui.edu.vn.
}

${ }^{*}$ Supervising author; ${ }^{+}$Corresponding au
Keywords: synthetic and natural wollastonite, larnite, epoxy compositions, rice husk, X-ray phase analysis, wear resistance.

\section{Abstract}

Every year around the world, as a result of rice threshing, about 600 million tons of rice husk waste are generated. They pollute the environment, since rice husks do not disintegrate in the ground, due to the presence of silicon dioxide in its composition. Silicon dioxide from rice husk ash differs from other known types of silicon-containing raw materials in that it is in an amorphous state, contains less metal impurities and is chemically more active.

At the same time, this amorphous silica can be effectively used in combination with limestone for the synthesis of promising types of fillers for polymer materials, in particular, wollastonite.

Based on the results of X-ray analysis, the phase composition of the synthesized filler samples was determined. It was shown that synthetic wollastonite, regardless of the synthesis temperature and the ratio of silicon dioxide and calcium carbonate in its composition, contains mainly $\beta$-wollastonite and larnite as impurities. A higher content of $\beta$-wollastonite in the composition of the synthesized filler samples is achieved at temperatures of their preparation in the range from 800 to $900{ }^{\circ} \mathrm{C}$. At the same time, in the case of wollastonite with a ratio of silicon dioxide and calcium carbonate $1: 1$, the synthesis temperature has a greater effect on its composition. Filling epoxy compositions, both natural and synthetic wollastonite, significantly increases their wear resistance. This effect is associated with the anisodiametric shape of the filler particles and is approximately the same when using natural and synthetic wollastonite, with a similar content of $\beta$ wollastonite in their composition.

\section{References}

[1] Yu.V. Gulaya, A.A. Dvornitsin, L.A. Lim. Prospects for the use of agricultural waste in the production of polymer composites. Young Scientist. 2017. No.21. P.27-30. (russian)

[2] P.I. Soroka. Physicochemical principles of the process of obtaining silicon dioxide from rice husks. National Bulletin Technical University "KPI". 2010. No.10. P.124-134. (russian)

[3] Nwosu-Obieogu Kenechi, Chiemenem Linus, Adekunle Kayode. Utilization of Rice Husk as Reinforcement in Plastic Composites Fabrication- A Review. American Journal of Materials Synthesis and Processing. 2016. Vol.1. No.3. P.32-36.

[4] N. Muslim, A. Hamzah, A. Al-kawaz. Study of mechanical properties of wollastonite filled epoxy functionally graded composite. Int. Journal of Mech. Engin. and Technology. 2018. Vol.9. No.8. P.669677. 
OPTIMIZATION OF THE TEMPERATURE FOR THE PRODUCTION OF SYNTHETIC WOLLASTONITE BASED... 18-23

[5] Elena Gotlib, Ha Phuong Thi Nya, Thi Lan Anh Nguyen, Alla G. Sokolova, Ekaterina Yamaleeva, Ildar N. Musin.Agricultural By-Products as Advanced Raw Materials for Obtaining Modifiers and Fillers for Epoxy Materials. Key Engineering Materials. 2019.Vol.822. P.343-349.

[6] E.M. Gotlib, E.S. Ilyicheva, A.G. Sokolova. Wollastonite as an effective filler for composite materials: textbook. allowance. Moscow: INEP. 2013. 87p. (russian)

[7] Hamisah Ismail, Roslinda Shamsudin, Muhammad Azmi, Abdul Hamid and Azman Jalar. Synthesis and Characterization of Nano-Wollastonite from Rice Husk Ash and Limestone. Materials Science Forum. 2013. Vol.756. P.43-47.

[8] E.M. Gotlib, R.V. Kozhevnikov, D.F. Sadykova, A.R. Hasanova, E.R. Galimov, E.S. Yamaleeva. Wollastonite - an effective filler for rubbers and composite materials based on linear and reticulated polymers: monograph. Germany: Lambert Publishing. 2017. 161p. 